\title{
VEGETATION INDICES FOR IRRIGATED CORN MONITORING
}

\author{
Francisco C. G. Alvino ${ }^{1 *}$, Catariny C. Aleman ${ }^{1}$, Roberto Filgueiras ${ }^{1}$, Daniel Althoff ${ }^{1}$, \\ Fernando F. da Cunha ${ }^{1}$
}

${ }^{1 *}$ Corresponding author. Universidade Federal de Viçosa/ Viçosa - MG, Brasil.

E-mail: cassioalvino2@gmail.com | ORCID ID: https://orcid.org/0000-0001-6047-9111

\begin{abstract}
KEYWORDS
vegetation cover, decision-making, remote sensing.
\end{abstract}

\begin{abstract}
Monitoring of large agricultural lands is often hampered by data collection logistics at field level. To solve such a problem, remote sensing techniques have been used to estimate vegetation indices, which can subsidize crop management decision-making. Therefore, this study aimed to select vegetation indices to detect variability in irrigated corn crops. Data were collected in São Desidério, Bahia State (Brazil), using an OLI sensor (Operational Land Imager) embedded to a Landsat- 8 satellite platform. Five corn growing plots under central pivot irrigation were assessed. The following vegetation indices were tested: NDVI (Normalized Difference Vegetation Index), EVI (Enhanced Vegetation Index), SAVI (Soil Adjusted Vegetation Index), GNDVI (Green Normalized Difference Vegetation Index), SR (Simple Ratio), NDWI (Normalized Difference Water Index), and MSI (Moisture Stress Index). Among the tested indices, SR was more sensitive to high corn biomass, while GNDVI, NDVI, EVI, and SAVI were more sensitive to low values. Overall, all indices were found to be concordant with each other, with high correlations among them. Despite this, the use of a set of these indices is advisable since some respond better to certain peculiarities than others.
\end{abstract}

\section{INTRODUCTION}

Conventional crop monitoring, mainly of large areas, is costly and ineffective. It is often done by surveying, at site, the entire area to find trouble spots, that is, with biotic and abiotic stresses. If observed late, these spots may cause irreversible impacts to crops, impairing production and increasing losses (Aggarwal, 2004; Mulianga et al., 2013).

Remote sensing has stood out as an alternative for monitoring crop fields. The technique can reduce time and costs, facilitating accurate and large-scale decision-making (Teixeira et al., 2009). It comprises a set of tools to obtain information on targets within the Earth's surface using distant or remote sensors, without physical contact, recording their interactions with electromagnetic radiation (Jensen \& Epiphanio, 2011; Formaggio \& Sanches, 2017). This favors identification of problems in the field, especially in large farming areas (Bernardi et al., 2017).

Radiation reflected from surface targets at varied electromagnetic spectrum amplitudes has been used to interpret crop vegetative vigor and guide management decisions. This reflected radiation is also used to establish relationships between vegetation indices and crop features observed in the field (Ponzoni et al., 2012; Zhang et al., 2012). Vegetation indices are based on algebraic operations between different spectral reflectances of sensors; they aim to enhance responses of interest of targets, enabling detection of further problems in vegetation monitoring (Ribeiro et al., 2017). Among several indices cited in the literature, there is no consensus on which is more suitable for crop monitoring. This is because some of them are more sensitive to low biomass, while others have greater sensitivity to high biomass (Bertolin et al., 2017; Kross et al., 2015; Jensen \& Epiphanio, 2011).

Normalized Difference Vegetation Index (NDVI) relates near-infrared and red bands and has a positive correlation with biomass. Studies have shown that such index is more sensitive to early plant growth stages (Jensen \& Epiphanio, 2011). Moreover, Green Normalized Difference Vegetation Index (GNDVI) is able to relate directly to photoactive pigments in plants and is distinguished from NDVI by using the green band instead of the red one (Gitelson et al., 1996).

Enhanced Vegetation Index (EVI) is has been proposed for vegetation biomass estimation, minimizing

\footnotetext{
${ }^{1}$ Universidade Federal de Viçosa/ Viçosa - MG, Brasil.
} 
soil reflectance effects and atmospheric influences. Yet, Soil Adjusted Vegetation Index (SAVI) is an index designed to consider soil effects on analyzed images if the land surface is not fully covered by vegetation.

Moisture Stress Index (MSI) and Normalized Difference Water Index (NDWI) quantify plant physiological stress due to water loss, detecting changes in relative water content in leaves (Hunt JR \& Rock, 1989. These indices are good predictors of water potential in vegetation canopy through spectral data (Rallo et al., 2014).

Given the widely varied indices, there is an urgent need to find one or a method that is sensitive to crop changes in the field, for all phenological stages. Identifying one or combination thereof could make satellite crop monitoring more efficient in terms of changes occurring in the field (Huete, 1988; Mulla, 2013; Tillack et al., 2014). In this context, this study aimed to analyze different vegetation indices to select one or a set of them that are responsive to irrigated corn crop changes.

\section{MATERIAL AND METHODS}

The study area is located in the city of São Desidério, Bahia Sate (Brazil). It is located at the geographical coordinates of $12^{\circ} 27^{\prime} 14^{\prime \prime} \mathrm{S}$ and $45^{\circ} 41^{\prime} 16^{\prime \prime} \mathrm{W}$, in the WGS84 reference system (Figure 1).

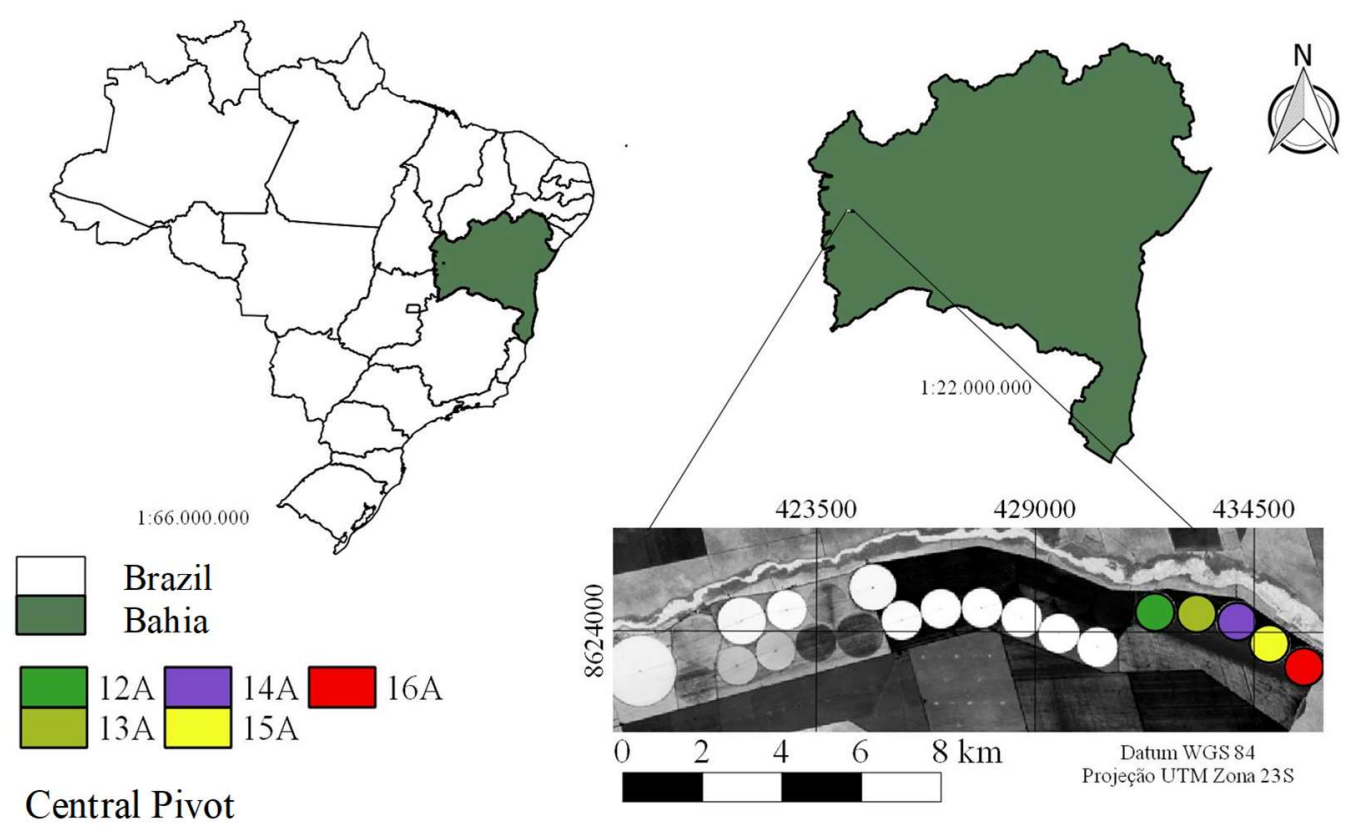

FIGURE 1. Study area location and central pivot identification.

According to Köppen's classification, the climate is characterized as $A w$ (tropical climate), with annual temperatures from 17 to $37^{\circ} \mathrm{C}$, and mean annual rainfall of $1056 \mathrm{~mm}$ (Barbosa et al., 2018; Soares Neto et al. 2013). The soil has the following physical-hydric traits: field capacity of $0.13 \mathrm{~cm}^{3} / \mathrm{cm}^{3}$; wilt point of $0.07 \mathrm{~cm}^{3} / \mathrm{cm}^{3}$, and apparent density of $1.55 \mathrm{~g} / \mathrm{cm}^{2}$. Central pivots were implanted on the area with corn crop sowing (cultivar Status Viptera 3). To facilitate management, the pivots were identified as 12A, 13A, 14A, 15A, and 16A (Bertolin et al., 2017). Table 1 shows the planting dates, harvest date, cycle duration, and accumulated irrigation depth for each central pivot in the 2015 harvest.

TABLE 1. Corn cycle dates and information for each center pivot.

\begin{tabular}{ccccc}
\hline Pivot & Sowing date & Harvest date & Cumulative irrigation depth $(\mathrm{mm})$ & Cycle duration (days) \\
\hline $12 \mathrm{~A}$ & $09 / 05 / 2015$ & $24 / 09 / 2015$ & 710,8 & 139 \\
$13 \mathrm{~A}$ & $12 / 05 / 2015$ & $24 / 09 / 2015$ & 708,4 & 136 \\
$14 \mathrm{~A}$ & $13 / 05 / 2015$ & $24 / 09 / 2015$ & 750,7 & 135 \\
$15 \mathrm{~A}$ & $15 / 05 / 2015$ & $24 / 09 / 2015$ & 678,9 & 133 \\
$16 \mathrm{~A}$ & $16 / 05 / 2015$ & $24 / 09 / 2015$ & 737,0 & 132 \\
\hline
\end{tabular}

Monitoring was done using multispectral images from the OLI sensor (Operational Land Imager), which is embedded in the Landsat- 8 satellite platform. This satellite provides images with $30-\mathrm{m}$ spatial resolution for visible and infrared short-wave spectra, and 16-day temporal resolution (Ariza, 2013; Roy et al., 2014). Images were acquired on a USGS (United States Geological Survey) portal, known as Earth Explorer. Then, they were selected for cloud interference. Vegetation indices were then estimated using seven cloud-free images for the entire cycle of irrigated corn.
After this procedure, images were redesigned for the southern hemisphere, in the WGS84 reference system and UTM Zone 23S projection. After being selected, images were corrected for atmospheric effects by DOS1 method (Chavez, 1996); then, digital numbers were converted to a physical basis, i.e., reflectance. Radiometric image conversion was performed following the method used by Ariza (2013), for bands 2 to 7, as in [eq. (1)], using the QGIS 2.8 software (QGIS Development Team, 2017). 


$$
L_{\lambda}=M_{L} Q_{c a l}+A_{L}
$$

Where:

$L_{\lambda}$ is the radiance at the top of the atmosphere;

$M_{L}$ is the specific scale multiplication factor (gain),

$A_{L}$ is the specific additive scale factor (offset). Both gain and offset are provided in the metadata file (MLT.txt).

Radiance of each band was converted into reflectance at the top of the atmosphere, in images from the OLI sensor, using [eq. (2)].

$$
\rho_{\lambda}=\frac{\pi \times L_{\lambda} \times d^{2}}{\operatorname{ESUN}_{\lambda} \times \operatorname{cosZ}}
$$

Where:

$\mathrm{L}_{\lambda}$ is the radiance of each band, in $\mathrm{W} \cdot \mathrm{m}^{-2} \cdot \mathrm{sr}^{-1} \cdot \mu \mathrm{m}^{-1}$;

$\operatorname{ESUN}_{\lambda}$ is the spectral irradiance at the top of the atmosphere, in W. $\mathrm{m}^{-2} \cdot \mathrm{sr}^{-1} \cdot \mu \mathrm{m}^{-1}$;

$\mathrm{Z}$ is the zenith angle (rad), and

$\mathrm{d}$ is the Earth-Sun distance, in astronomical units, provided by the Landsat- 8 image metadata file.

Figure 2 is an explanatory flowchart of the method used in this study.

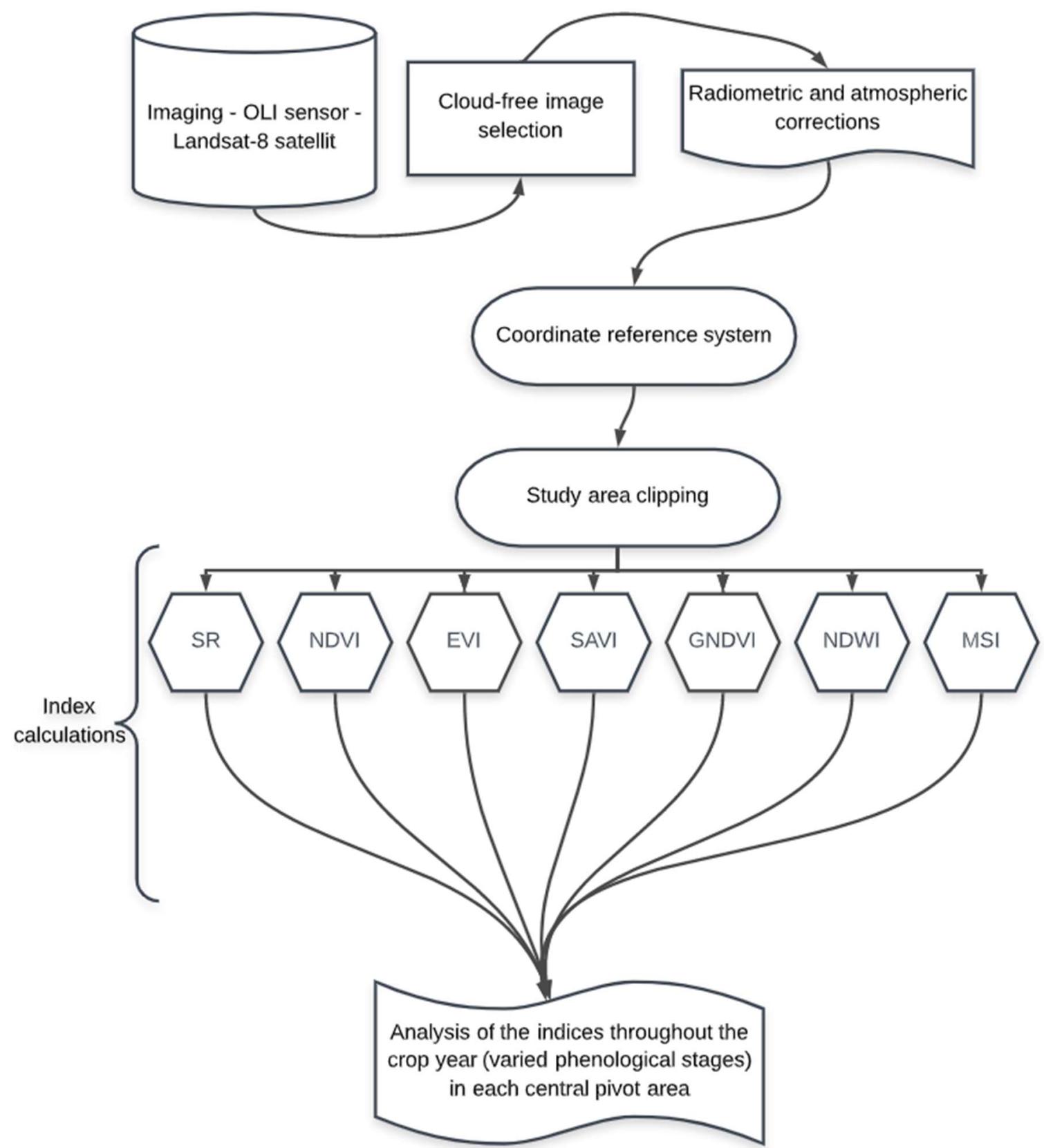

FIGURE 2. Methodological process for obtaining vegetation indices for analysis of irrigated corn crop behavior.

After image selection and pre-processing, vegetation indices were calculated according to Equations 3 to 9. The adopted indices were: NDVI, EVI, SAVI, GNDVI,
SR, NDWI, and MSI. Each of them has special features that set it apart from the others, which instigates analysis of its use in monitoring irrigated corn crops. 
TABLE 2. Algebraic and authorial descriptions of the indices used in the study.

\begin{tabular}{|c|c|c|}
\hline Index & Author & Equation $\mathrm{n}^{\circ}$ \\
\hline $\mathrm{NDVI}=\frac{\rho \mathrm{NIR}-\rho \mathrm{RED}}{\rho \mathrm{NIR}+\rho \mathrm{RED}}$ & (Rouse JR et al., 1974) & (3) \\
\hline $\mathrm{EVI}=\mathrm{G} \times \frac{\rho \mathrm{NIR}-\rho \mathrm{RED}}{\rho \mathrm{NIR}+\mathrm{C} 1 \times \rho \mathrm{RED}-\mathrm{C} 2 \times \rho \mathrm{Blue}+\mathrm{L}}(1+\mathrm{L})$ & (Liu \& Huete, 1995) & (4) \\
\hline $\mathrm{SAVI}=\frac{(\rho \mathrm{NIR}-\rho \operatorname{Red})(1+\mathrm{L})}{\rho \mathrm{NIR}+\rho \operatorname{Red}+\mathrm{L}}$ & (Huete, 1988) & $(5)$ \\
\hline $\mathrm{GNDVI}=\frac{\rho N I R-\rho V E R D E}{\rho N I R+\rho V E R D E}$ & (Gitelson et al., 1996) & (6) \\
\hline $\mathrm{SR}=\frac{\rho \mathrm{NIR}}{\rho \mathrm{RED}}$ & (Birth \& Mcvey, 1968) & (7) \\
\hline $\mathrm{MSI}=\frac{\rho \mathrm{SWIR} 1}{\rho N I R}$ & (Hunt JR \& Rock, 1989) & (8) \\
\hline $\mathrm{NDWI}=\frac{\rho \mathrm{NIR}-\rho \mathrm{SWIR} 1}{\rho \mathrm{NIR}+\rho \mathrm{SWIR} 1}$ & $(\mathrm{Gao}, 1996)$ & (9) \\
\hline
\end{tabular}

Where: $\rho$ Green - green-band reflectance; $\rho$ Red - red-band reflectance; $\rho$ NIR $=$ near-infrared reflectance; $\rho$ NIR $=$ short-wave infrared reflectance; $\mathrm{L}=$ adjustment factor in equations 4 and 5 , which may vary from 0 to $1 ; \mathrm{C} 1$ and $\mathrm{C} 2$ are adjustment coefficients for aerosol effects in the atmosphere; and $\mathrm{G}$ adjusted gain. Coefficients in Eq. 4 are in accordance with the literature, namely, $\mathrm{L}=0.5, \mathrm{C} 1=6, \mathrm{C} 2=7.5$, and $\mathrm{G}=$ 2.5 (Huete, 1988; Justice et al., 2002; Ponzoni et al., 2012).

Data for processing indices were extracted from all central pivots (Figure 1). After calculating indices in each central pivot, for different dates of image acquisition, phenological behavior of corn crops was assessed over a cycle, for each index, qualitatively and quantitatively.

\section{RESULTS AND DISCUSSION}

Figures 3 to 9 show the vegetation indices used for monitoring of irrigated corn crop in five central pivots. These figures depict the phenological stages of corn cropping, from germination to senescence. Between July 28, 2015 and August 29, 2015, crop reached the highest vegetative vigor according to a holistic analysis of all indices. Within these dates, crop had been sown for 73 and 105 days in pivot 16A; 74 and 106 days in pivot 15A; 76 and 108 days in pivot 14A; 77 and 109 days in pivot 13A; and 80 and 112 days in pivot 12A. For all five central pivots, corn crop was spread over the entire area, highlighting vegetative (VT)/reproductive (R1) stages on July 28, 2015 and reproductive R4/R5 on August 29, 2015.

Regarding the sensitivity of all indices on different dates, the descriptive boxplot analysis in Figures 3 to 9 show that EVI (Figure 4) and SR (Figure 6) were more effective in discriminating differences from July 10, 2015 to August 29,2015 . This was confirmed by a greater range of the boxplots referring to the SR when compared to the other indices, in addition to the differentiation observed on August 13, 2015 and August 29, 2015 for EVI. Conversely, the other indices were more sensitive in early crop stages, on May 25, 2015 and June 10, 2015, showing an increased capacity for differentiating low-biomass vegetation.
Figure 3 shows the results of NDVI, which ranged between 0.14 and 0.93 , in which, the acquired image displayed lower values on the first date (May 25, 2015). Therefore, on this date, there was a predominance of exposed soil in the study areas, that is, plants were in emergency or germination stages, as exhibited in Table 1.

NDVI ranges from -1.0 to 1.0 , wherein the closer to the unity, the higher the vegetation cover density. Negative values are mostly associated with water bodies or clouds (Ponzoni et al., 2012). For Souza et al. (2009), NDVI is related to irrigated-corn phenological stages and increases as plants grow.

Studies by Gameiro et al. (2017) showed high NDVI in vegetation with greater biomass and good water availability in the soil, while in less dense vegetation and with exposed soil, NDVI is lower.

NDVI low sensitivity between July 10, 2015 and August 29, 2015 is mainly due to its saturation in highbiomass conditions (Jensen \& Epiphanio, 2011). It tends to occur during flowering and grain-filling stages, when corn crops reach greater biomass. Under these conditions, NDVI tends to vary less along agricultural parcels, as shown in Figure 3.

From September 14 to 30, 2015, there was a significant drop in NDVI, that is, vegetation lost its vigor, indicating that crop had started its maturation process and hence senescence. This corroborates with the finding of Risso et al. (2012), who observed low NDVIs during senescence of soybeans. 


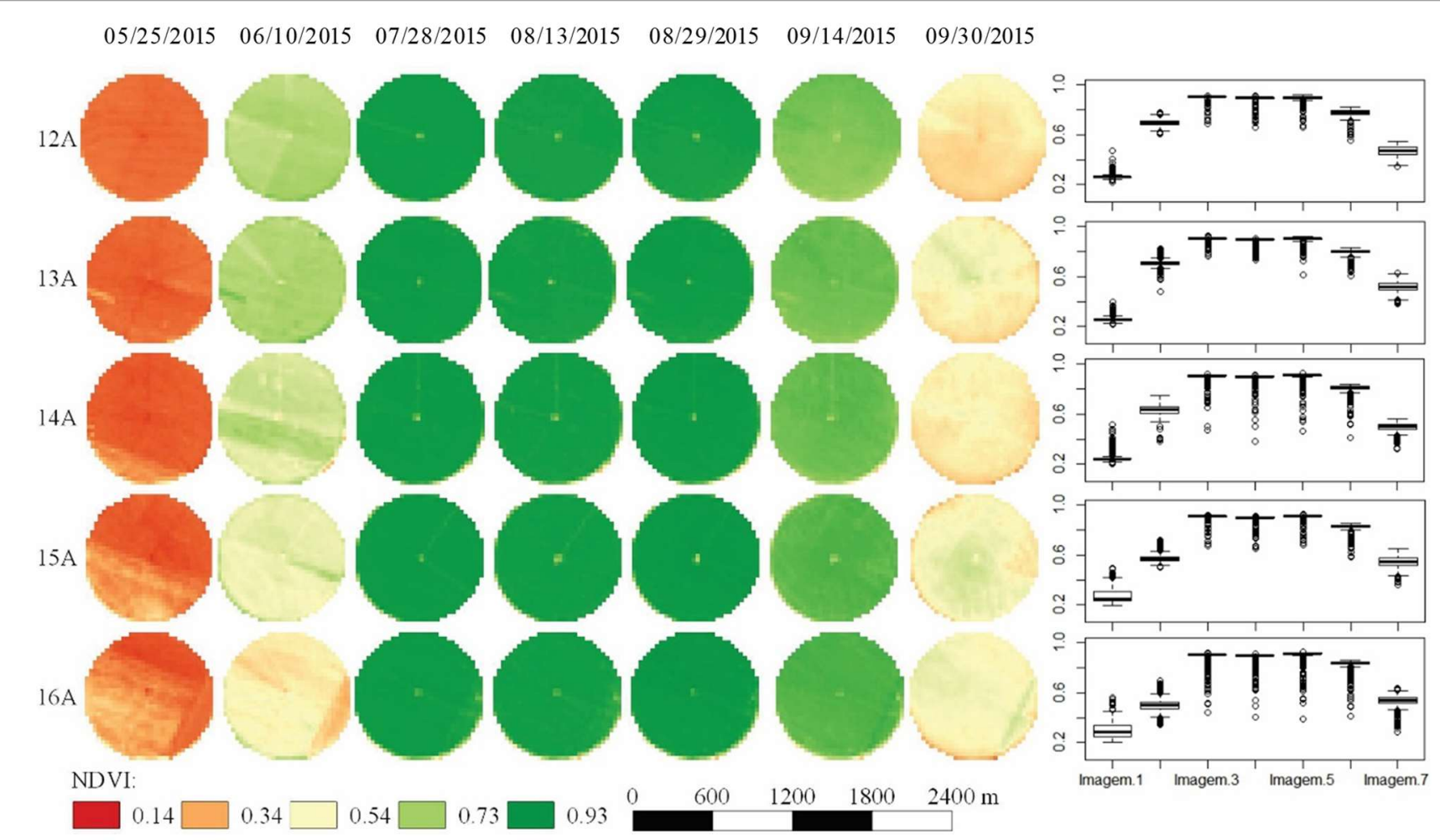

FIGURE 3. NDVI for five different irrigation pivots on seven different dates during irrigated corn cycle in 2015 , followed by descriptive statistics (Boxplot) of vegetation indices of the studied farm for the dates of acquired images.

Figure 4 displays EVI index response, which were similar to that of NDVI. However, EVI had a slight decrease between August 13 and 29, 2015. Thus, this index was more sensitive to high-biomass crops since corn was no longer in full vegetative vigor (R4/R5) on August 29, 2015. For Latorre et al. (2003), EVI is a vegetation index developed to improve sensitivity in areas with higher biomass density values and smooth influence of signals from soil.

Figure 5 shows SAVI temporal dynamics. This index has an adjustment factor to attenuate soil effects on crop spectral responses. Like EVI (Figure 4), SAVI decreased between August 13 and 29, 2015. Therefore, such adjustment factor (L) is important in the equation since it differentiates SAVI from NDVI.

A suitable adjustment of the L factor in SAVI index could improve even more results. However, for this, more data is required, what makes the method complex. By contrast, values between 0.25 and 1.0 , depending on the amount of crop biomass (Boratto \& Gomide, 2013) may be subjective.

As in our study, Rosendo (2005) observed similarities between EVI and SAVI indices for agricultural crop monitoring, using MODIS/TERRA images. This author followed monthly and seasonally changes in these indices in various crops (pasture, irrigated crops, and coffee) and at different phenological stages.

When monitoring forest plantations and native forests by NDVI and SAVI, Leite et al. (2017) found that both indices are able to detect forest cover changes. These authors also concluded that both indices had similar results; however, in high vegetation density sites, NDVI proved to be more suitable if compared to SAVI. 
$\begin{array}{lllllll}05 / 25 / 2015 & 06 / 10 / 2015 & 07 / 28 / 2015 & 08 / 13 / 2015 & 08 / 29 / 2015 & 09 / 14 / 2015 & 09 / 30 / 2015\end{array}$

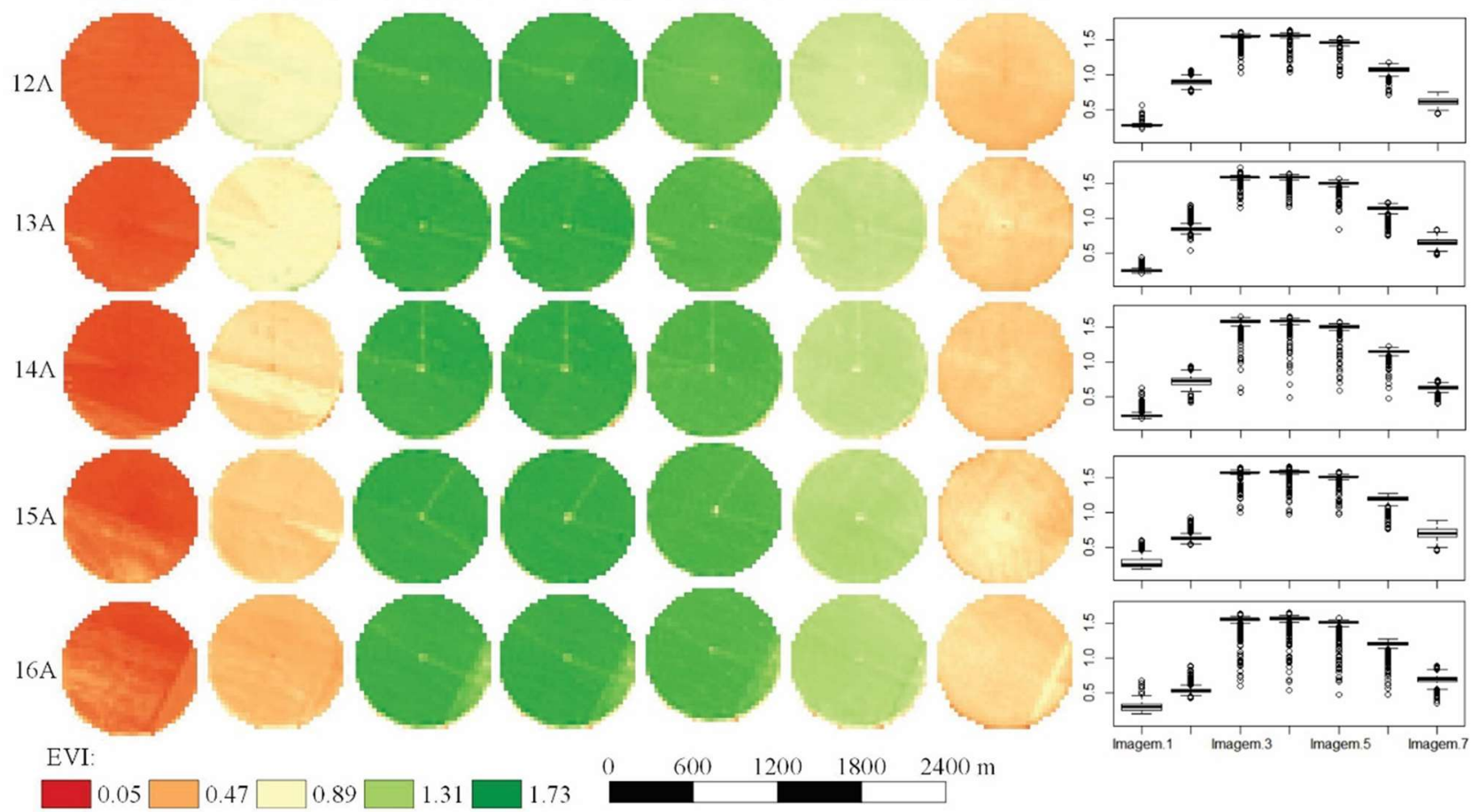

FIGURE 4. EVI for five different irrigation pivots on seven different dates during irrigated corn cycle in 2015, followed by descriptive statistics (Boxplot) of vegetation indices of the studied farm for the dates of acquired images.

Between July 28 and August 13, 2015, corn crop was between vegetative and grain-filling stages, respectively, wherein SAVI reached the highest value (0.73) during reproductive stage (Figure 5). Likewise, Gameiro et al. (2017) observed SAVI of 0.7 during fruiting in irrigated fruit trees.
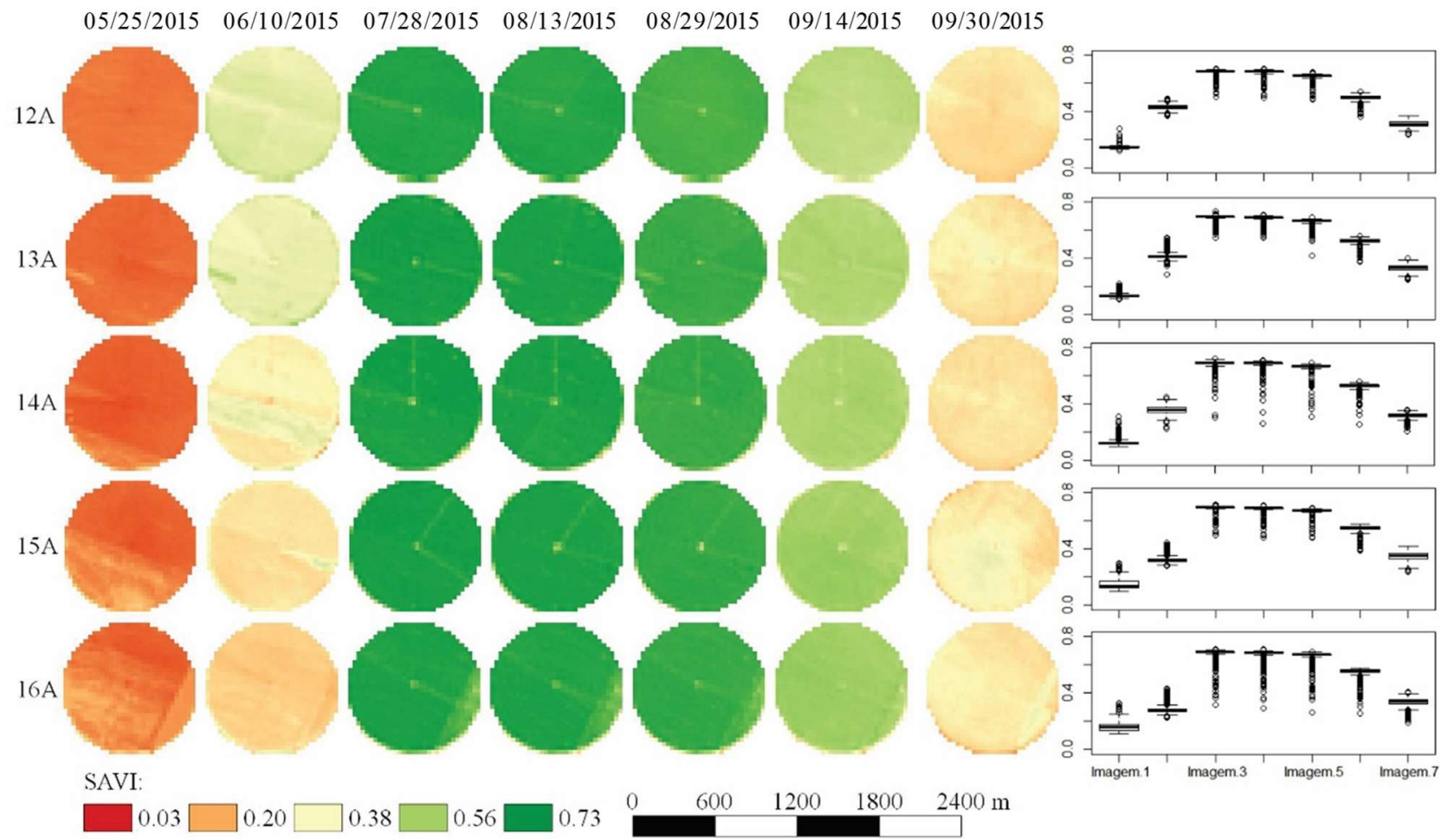

FIGURE 5. SAVI for five different irrigation pivots on seven different dates during irrigated corn cycle in 2015 , followed by descriptive statistics (Boxplot) of vegetation indices of the studied farm for the dates of acquired images. 
Figure 6 presents the results of SR. Based on image and boxplot analyses, we observed that such index could discriminate changes in crop phenological stage, in addition to being more sensitive to high biomass (between July 28 and August 29, 2015). Jensen \& Epiphanio (2011) also pointed out SR as more sensitive to high biomass but less sensitive to low amounts.

SR could discriminate crops in each central pivot on August 29, 2015 (Figure 6). It can be evidenced by a darker shade of green in pivots $14 \mathrm{~A}, 15 \mathrm{~A}$, and $16 \mathrm{~A}$ when compared to those in $12 \mathrm{~A}$ and $13 \mathrm{~A}$. It noteworthy mentioning that this finding was not made for the other indices.

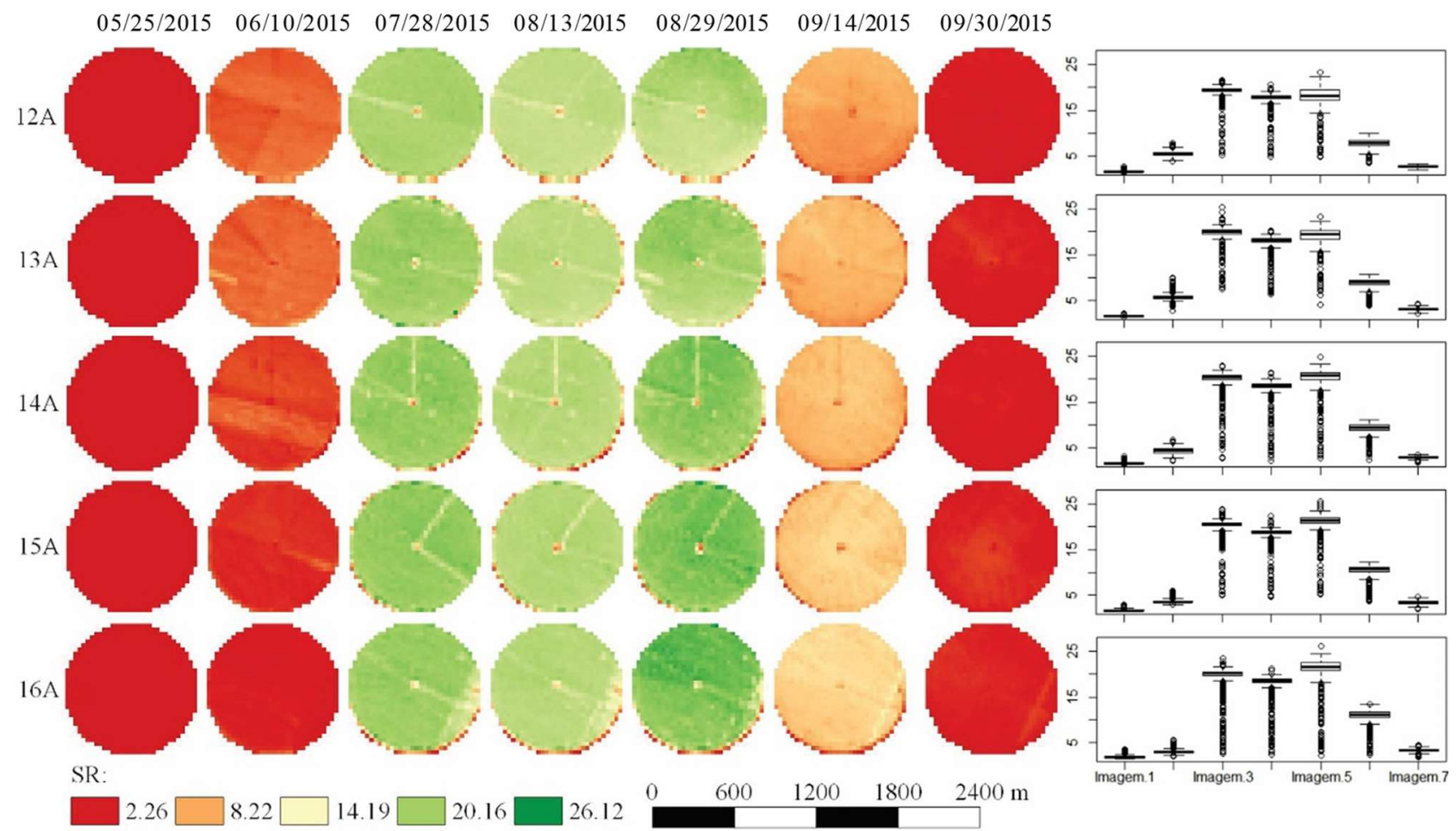

FIGURE 6. SR for five different irrigation pivots on seven different dates during irrigated corn cycle in 2015, followed by descriptive statistics (Boxplot) of vegetation indices of the studied farm for the dates of acquired images.

The behavior of GNDVI on all analyzed dates and central pivots can be seen in Figure 7. This index is a modification of NDVI where the red band is replaced with the green band. If compared to NDVI, this index had a lower sensitivity on May 25, 2015 for pivots 15A and 16A. On that date, corn had only 10 DAS, that is, in initial emergence, which shows the lower capacity of this index to differentiate surfaces. Such lower sensitivity is related to a greater similarity of the green spectral response to exposed soils and vegetation, which does not occur with the red wavelength spectrum.

Regarding phenological changes, GNDVI also showed less sensitivity compared to NDVI between August 29 and September 14, 2015. During this period, NDVI decreases (Figure 3) were more abrupt than those of GNDVI (Figure 7). This is because of the green band, which corresponds less to plant physiological changes and more to small changes in plant vigor. Moreover, Silva Júnior et al. (2008) verified that GNDVI was more sensitive than NDVI to identify chlorophyll concentration in forage plants. 


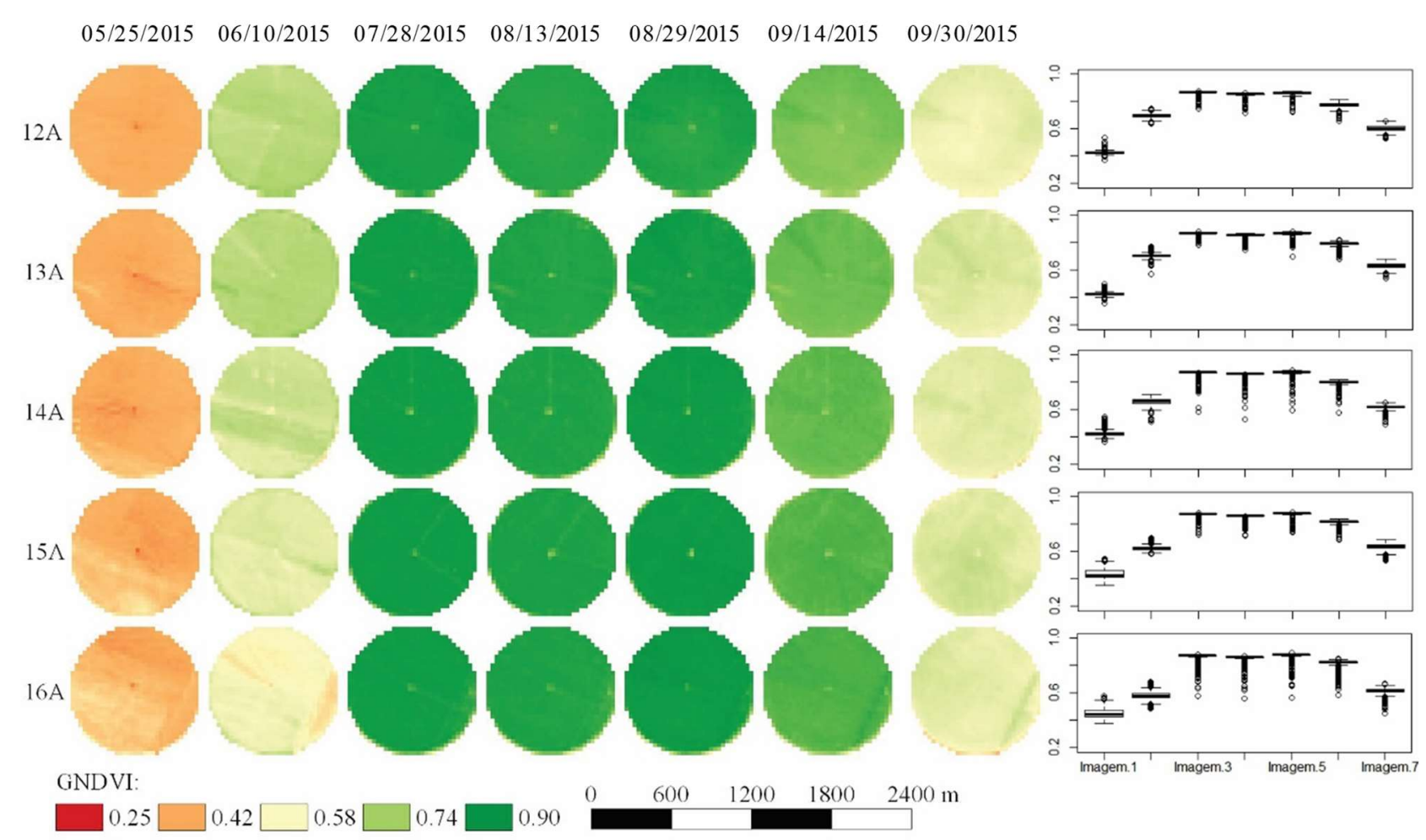

FIGURE 7. GNDVI for five different irrigation pivots on seven different dates during irrigated corn cycle in 2015 , followed by descriptive statistics (Boxplot) of vegetation indices of the studied farm for the dates of acquired images.

MSI had a high sensitivity to water content changes in corn canopy since as crop stage changed, irrigation demand increased and hence MSI decreased (Figure 8). Such sensitivity can be explained through MSI equation, in which it is the ratio between short-wave infrared spectral and near-infrared spectral responses.

Short-wave infrared has a higher absorption behavior when leaf water content increases, while near infrared does not tend to show absorption directly related to leaf water contents (Hunt JR \& Rock, 1989). This fact warns that higher MSI values indicate lower water contents in crop canopy. The same was seen in the study of Elhag \& Bahrawi (2017), who noted that plants under water stress have high MSI indices.

The high MSI values in Figure 8 are not indicative of lower canopy water content since plants were in the beginning of the vegetative period (May 25, 2015), when soil is more exposed. During tasseling (July 28, 2015) and grain filling (August 13, 2015), MSI was around 0.27, as seen in the third and fourth images in Figure 8. Overall, irrigated corn behavior was well evidenced by this index, as it varied with crop water demand.

The first and second images in Figure 8 show the presence of exposed soil, which corresponds to crop germination and the onset of the third and seventh fully developed leaves, when corn requires less water. Benabdelouahab et al. (2015) found good correlations between MSI and water content in wheat canopy during growth and grain filling. By using multiple data from time series and MSI index, Yu et al. (2018) could detect disturbances in forest species due to water stress. 


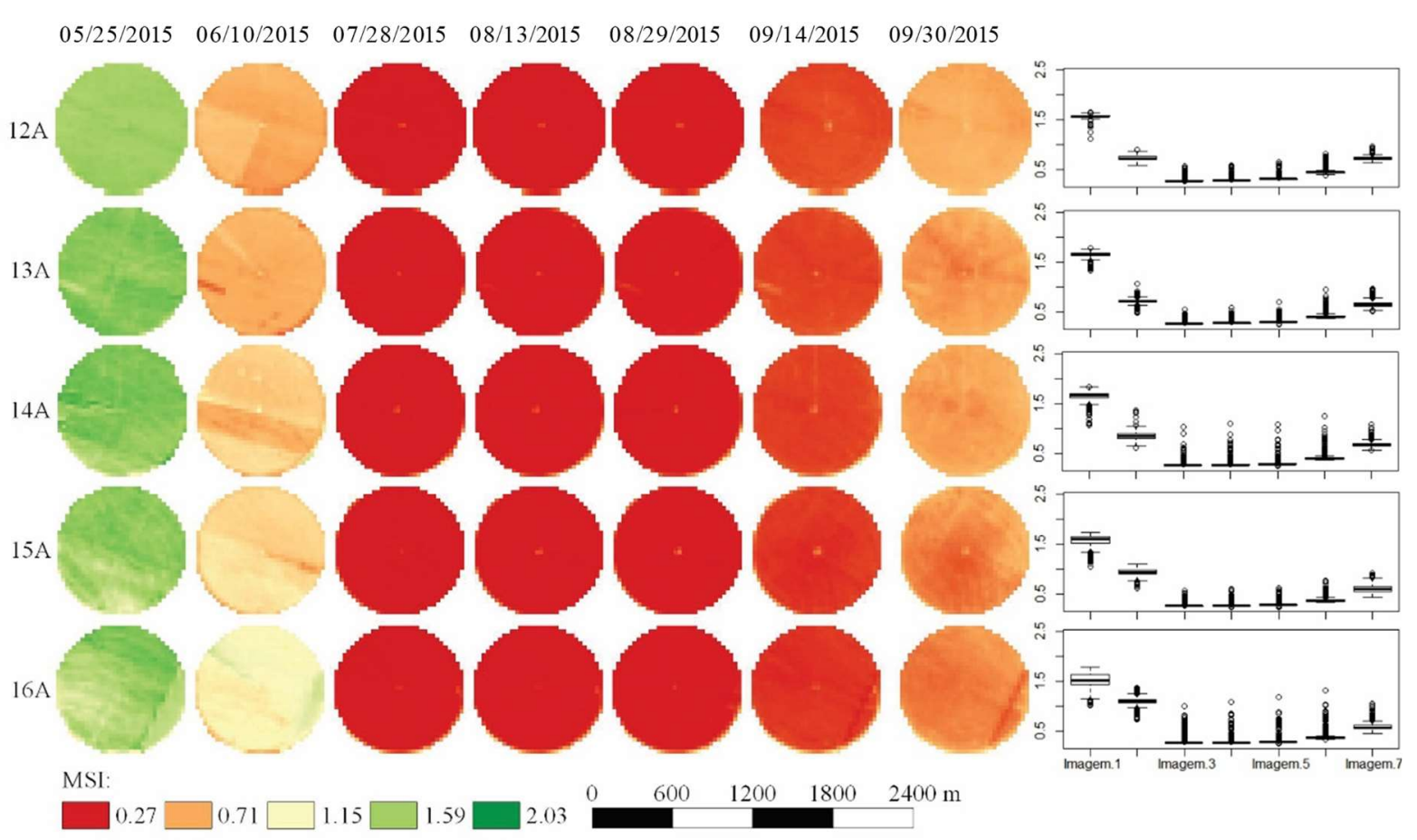

FIGURE 8. MSI for five different irrigation pivots on seven different dates during irrigated corn cycle in 2015, followed by descriptive statistics (Boxplot) of vegetation indices of the studied farm for the dates of acquired images.

Another index with direct correspondence to corn canopy water content was NDWI (Figure 9). This index is important for analysis in irrigated areas. The results in irrigated corn showed its ability to monitor and relate significantly to water contents in corn canopy. The index increased from -0.34 to 0.61 , as crop water demand increased. Between May 25 and June 10, 2015, this index may show negative values in corn as a result of low vegetation biomass and due to exposed soil areas. As for Gao (1996), Ceccato et al. (2001), and Gu et al. (2013), NDWI ranges between -1 and +1 , depending on crop water content, vegetation species, ground cover and bottom effect.
A high NDWI, green color, corresponds to high water content in vegetation and wider vegetation cover, whereas negative NDWI, red color, corresponds to low vegetation biomass and more exposed soil, as crops in central pivots are subjected to irrigation management. Gu et al. (2013) achieved significant results when using NDWI to detect and monitor canopy moisture in plants grown in large farming areas. Our findings on MSI and NDWI, along with those of the above-mentioned studies, demonstrate the ability of these indices to monitor changes in vegetation water content, and thus can be used to improve irrigation and crop monitoring.

$\begin{array}{lllllll}05 / 25 / 2015 & 06 / 10 / 2015 & 07 / 28 / 2015 & 08 / 13 / 2015 & 08 / 29 / 2015 & 09 / 14 / 2015 & 09 / 30 / 2015\end{array}$

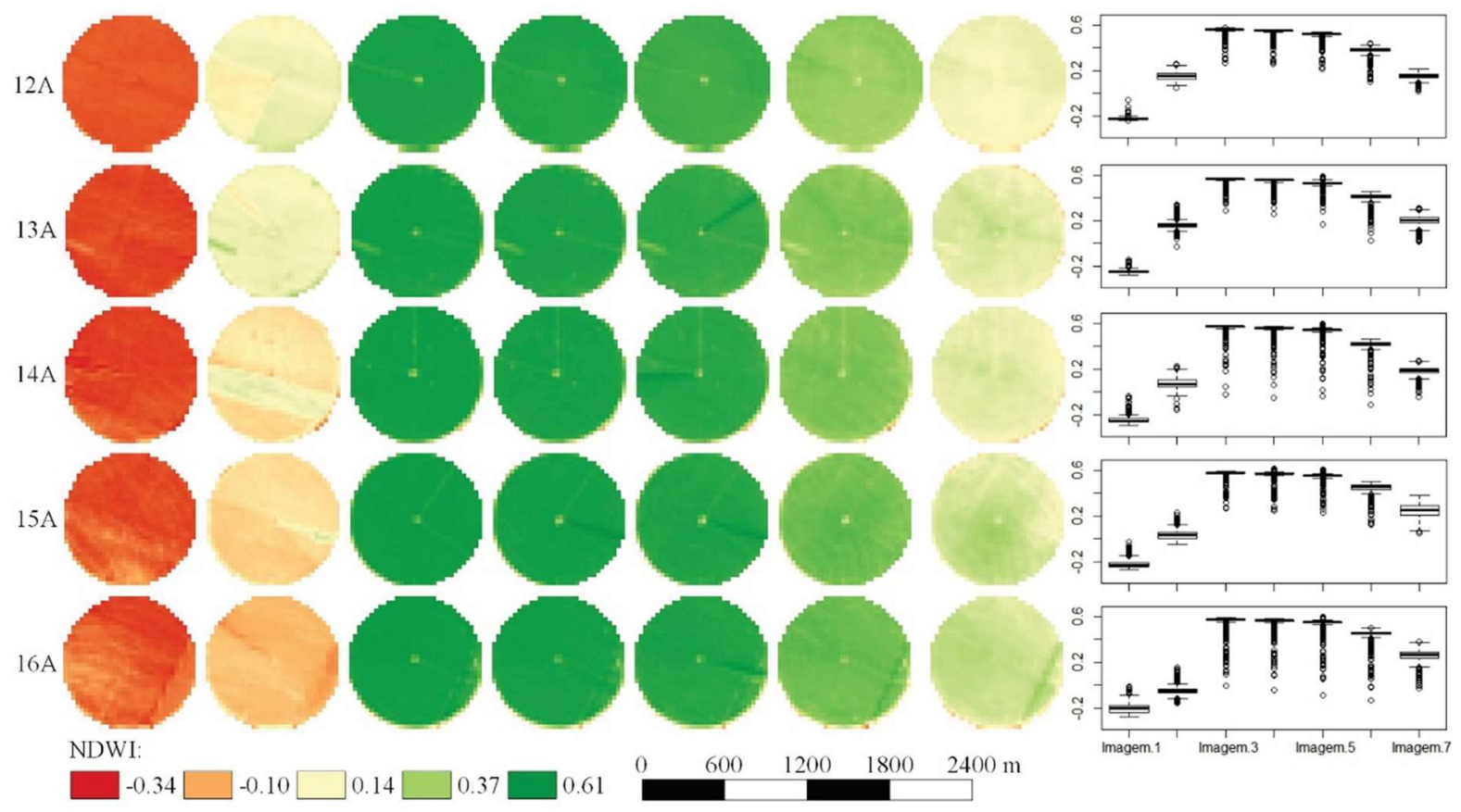

FIGURE 9. NDWI for five different irrigation pivots on seven different dates during irrigated corn cycle in 2015 , followed by descriptive statistics (Boxplot) of vegetation indices of the studied farm for the dates of acquired images. 
Figure 10 shows that all vegetation índices had correlations with each other, which can be seen by the scatter plots, wherein some indices are more sensitive to biomass than are others. The correlation coefficients were positive among all indices except for those involving MSI. Although correlations of the other indices with MSI were negative, these were extremely high.

When correlated with NDVI, the indices GNDVI, SAVI, and EVI showed high correlations, with coefficients of $0.996,0.983$, and 0.974 , respectively. Such correlations indicate similarities and strong relationship among them, all being good indicators of biomass in vegetation. But, when these indices were analyzed during corn reproductive stage, they showed slight differences, among which EVI was more sensitive than GNDVI, NDVI, and SAVI.

The indices that showed correspondence with leaf water content (MSI and NDWI) also showed high correlation between each other. What justifies their similar behavior and sensitivity to changes in plant water content. Nonetheless, NDWI was more sensitive during the end of the crop cycle, which can be observed by its greater values compared to those of MSI, between September 14 and 30, 2015. Zhang et al. (2018) also observed that estimation of water content in wheat canopy using such indices, based on the Sentinel-2 band reflectance, was feasible and can be used to support irrigation decision-making.

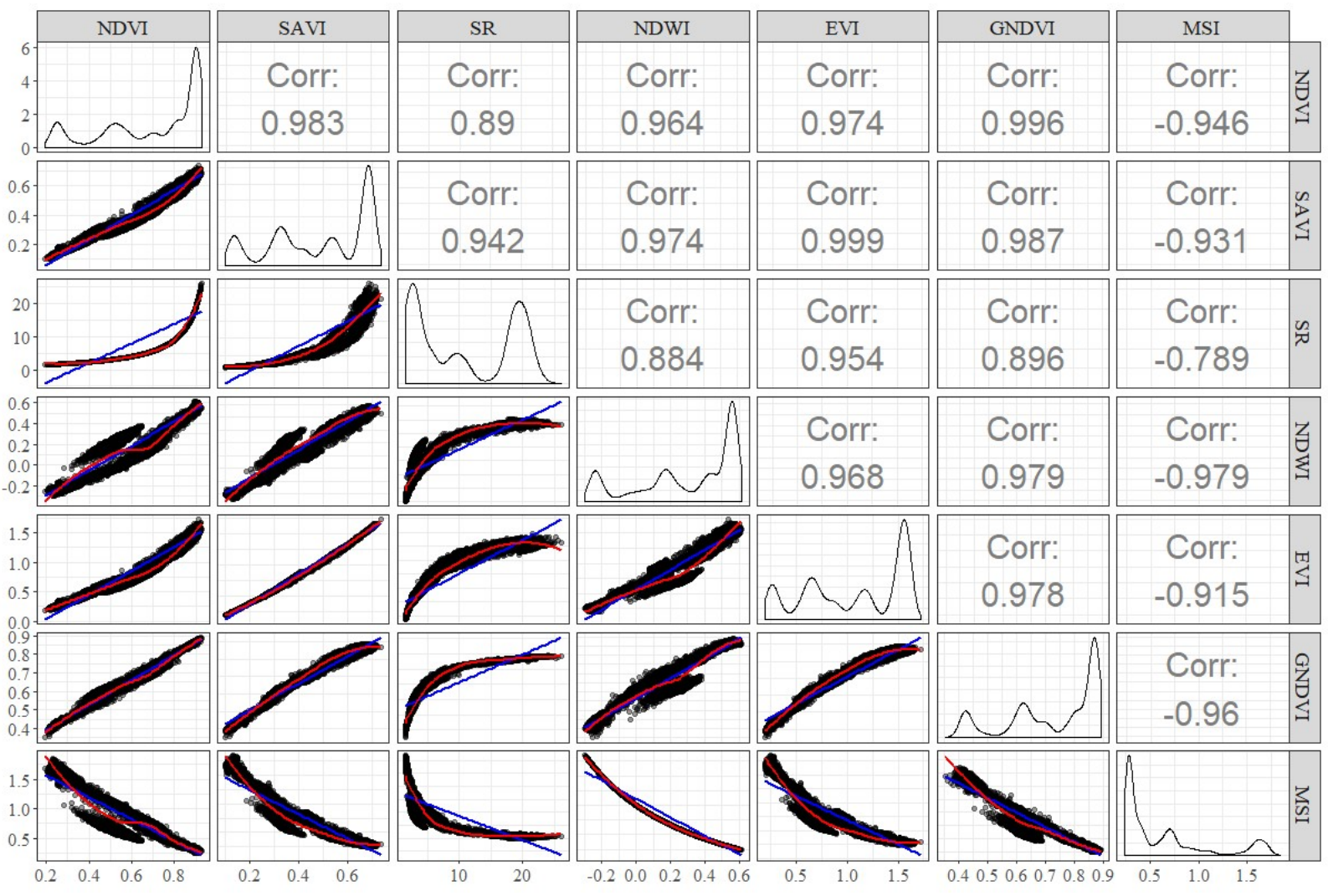

FIGURE 10. Correlation between the studied vegetation indices, wherein the blue line represents the fitted linear model and the red line the fitted local regression model.

\section{CONCLUSIONS}

All the studied indices are suitable tools for irrigated corn management and monitoring since they detect vegetation cover changes quickly and at low operational cost.

NDVI, EVI, and SAVI showed better results during corn crop development, even though NDVI was less sensitive to high biomass amounts and SAVI was subjective in terms of adjustment factor weight. SR showed the highest sensitivity during tasseling and grain-filling. Yet, MSI and NDWI can be used as further information regarding leaf water content in corn plants.

In general, all indices were concordant with each other, therefore, all can all be used to discriminate corn phenological stages. However, the use of a set of these indices is advisable since some respond better to certain peculiarities than others.

\section{ACKNOWLEDGMENTS}

This study was financed in part by the Coordenação de Aperfeiçoamento de Pessoal de Nível Superior - Brasil (CAPES) - Finance Code 001

\section{REFERENCES}

Aggarwal S (2004) Principles of remote sensing. In: Training Workshop. Dehra Dun, World Meteorological Organization, Proceedings...

Ariza A (2013) Descripción y corrección de productos Landsat 8 LDCM (Landsat Data Continuity Mission). Bogotá, Instituto Geográfico Agustín Codazzi.

Barbosa AS, Santos GB, Dia SE, Siqueira ES, Silva JR, Barbosa VD (2018) Principais fatores condicionantes da formação e implicações para uso de Cambissolos em São Desidério, Oeste da Bahia. Revista Espinhaço 7(1):2-10. 
Benabdelouahab T, Balaghi R, Hadria R, Lionboui H, Minet J, Tychon B (2015) Monitoring surface water content using visible and short-wave infrared SPOT-5 data of wheat plots in irrigated semi-arid regions. International Journal of Remote Sensing 36(15):4018-4036. DOI: https://doi.org/10.1080/01431161.2015.1072650

Bernardi ACC, Grego CR, Andrade RG, Rabelo LM, Inamasu RY (2017) Spatial variability of vegetation index and soil properties in an integrated crop-livestock system. Revista Brasileira de Engenharia Agrícola e Ambiental 21 (8):513-518. DOI: https://doi.org/10.1590/18071929/agriambi.v21n8p513-518

Bertolin NO, Filgueiras R, Venancio LP, Mantovani EC (2017) Predição da produtividade de milho irrigado com auxílio de imagens de satélite. Revista Brasileira de Agricultura Irrigada 11(4):1627-1638. DOI: https://doi.org/10.7127/rbai.v11n400567

Birth GS, Mcvey GR (1968) Measuring the color of growing turf with a reflectance spectrophotometer. Agronomy Journal 60(6):640-643. DOI: https://doi.org/10.2134/agronj1968.00021962006000060016x

Boratto IM, Gomide RL (2013) Aplicação dos índices de vegetação NDVI, SAVI e IAF na caracterização da cobertura vegetativa da região Norte de Minas Gerais. Embrapa Milho e Sorgo-Artigo em anais de congresso (ALICE). Anais...In: Simpósio Brasileiro de Sensoriamento Remoto. São José dos Campos, INPE, Anais...

Ceccato P, Flasse S, Tarantola S, Jacquemoud S, Grégoire, JM (2001) Detecting vegetation leaf water content using reflectance in the optical domain. Remote Sensing of Environment 77(1):22-33. DOI:

https://doi.org/10.1016/S0034-4257(01)00191-2

Chavez PS (1996) Image-Based Atmospheric Corrections: Revisited and Improved. Photogrammetric Engineering and Remote Sensing 62(9):1025-1036.

Elhag M, Bahrawi JA (2017) Soil salinity mapping and hydrological drought indices assessment in arid environments based on remote sensing techniques. Geoscientific Instrumentation Methods and Data Systems 6:149-158

Formaggio AR, Sanches ID (2017) Sensoriamento remoto em agricultura. São Paulo, Oficina de Textos, 288 p.

Gameiro S, Teixeira CPB, Silva Neto TA, Lopes MFL, Duarte CR, Souto MVS, Zimback CRL (2017) Avaliação da cobertura vegetal por meio de índices de vegetação (NDVI, SAVI e IAF) na Sub-Bacia Hidrográfica do Baixo Jaguaribe, CE. Terræ 13(1-2):15-22.

Gao B (1996) NDWI-A normalized difference water index for remote sensing of vegetation liquid water from space. Remote Sensing of Environment 58(3):257-266. DOI: https://doi.org/10.1016/S0034-4257(96)00067-3

Gitelson AA, Kaufman YJ, Merzlyak MN (1996) Use of a green channel in remote sensing of global vegetation from EOS-MODIS. Remote sensing of Environment 58(3):289298. DOI: https://doi.org/10.1016/S0034-4257(96)00072-7
Gu Y, Wylie BK, Howard DM, Phuyal KP, Ji L (2013)

NDVI saturation adjustment: A new approach for improving cropland performance estimates in the Greater Platte River Basin, USA. Ecological Indicators 30:1-6. DOI: https://doi.org/10.1016/j.ecolind.2013.01.041

Huete AR (1988) A soil-adjusted vegetation index (SAVI). Remote sensing of environment 25(3):295-309. DOI: https://doi.org/10.1016/0034-4257(88)90106-X

Hunt JR ER, Rock BN (1989) Detection of changes in leaf water content using near-and middle-infrared reflectances. Remote Sensing of Environment 30(1):43-54. DOI: https://doi.org/10.1016/0034-4257(89)90046-1

Jensen JR, Epiphanio JCN (2011) Sensoriamento remoto do ambiente: uma perspectiva em recursos terrestres. São José dos Campos, Parêntese, 598p.

Justice CO, Townshend JRG, Vermote EF, Masuoka E, Wolfe RE, Salcous N, Roy DP, Morisette JT (2002) An overview of MODIS Land data processing and product status. Remote Sensing of Environment 83(1-2):3-15. DOI: https://doi.org/10.1016/S0034-4257(02)00084-6

Kross A, McNairn H, Lapen D, Sunohara M, Champagne C (2015) Assessment of RapidEye vegetation índices for estimation of leaf area index and biomass in corn and soybean crops. International Journal of Applied Earth Observation and Geoinformation 34:235-248. DOI: https://doi.org/10.1016/j.jag.2014.08.002

Latorre ML, Anderson LO, Shimabukuro YE, Carvalho Júnior OA de (2003) Sensor Modis: Características Gerais e Aplicações. Espaço \& Geografia 6(1):91-121.

Leite AP, Santos GR, Santos JE (2017) Análise temporal dos índices de vegetação NDVI e SAVI na estação experimental de Itatinga utilizando imagens landsat. Revista Brasileira de Energias Renováveis 6(4):606-623.

Liu HQ, Huete A (1995) A feedback based modification of the NDVI to minimize canopy background and atmospheric noise. IEEE Transactions on Geoscience and Remote Sensing 33(2):457-465. DOI: https://doi.org/10.1109/TGRS.1995.8746027

Mulianga B, Bégué A, Simoes M, Todoroff P (2013) Forecasting Regional Sugarcane Yield Based on Time Integral and Spatial Aggregation of MODIS NDVI. Remote Sens (5):2184-2199. DOI: https://doi.org/10.3390/rs5052184

Mulla DJ (2013) Twenty five years of remote sensing in precision agriculture: Key advances and remaining knowledge gaps. Biosystems Engineering 114(4):358-371. DOI: https://doi.org/10.1016/j.biosystemseng.2012.08.009

Ponzoni F, Shimabukuro Y, Kuplich T (2012)

Sensoriamento remoto da vegetação. São Paulo, Oficina de Textos, 2 ed. $176 \mathrm{p}$.

QGIS Development Team (2017) Sistema de informações geográficas QGIS. Mundo, Fundação Geoespacial de Código Aberto. Available: http://qgis.osgeo.org [Links]. 
Rallo G, Minacapili M, Ciraolo G, Provenzano G (2014) Detecting crop water status in mature olive groves using vegetation spectral measurements. Biosystems Engineering, Special Issue: Irrigated Agriculture: Water Resources Management for a Sustainable Environment 128:52-68. DOI: https://doi.org/10.1016/j.biosystemseng.2014.08.012

Ribeiro RB, Filgueiras R, Ramos MCA, Almeida LT, Generoso TN, Monteiro LIB (2017) Variabilidade espaçotemporal da condição da vegetação na agricultura irrigada por meio de imagens sentinel-2a . Revista Brasileira de Agricultura Irrigada 11(6):1884-1893. DOI: https://doi.org/10.7127/rbai.v11n600648

Risso J, Rizzi R, Rudorff BFT, Adami M, Shimabukuro YE, Formaggio AR, Epiphanio RDV (2012) Índices de vegetação modis aplicados na discriminação de áreas de soja pesquisa agropecuária brasileira 47(9):1317-1326.

Rosendo JS (2005) A Utilização de Sensores com Resolução Moderada (Modis) no Estudo da Vegetação na Bacia do Rio Araguari - Mg. Sociedade \& Natureza 33(17):91-104.

Rouse JR W, Haas RH, Schell JA, Deering DW (1974) Monitoring vegetation systems in the Great Plains with ERTS.

Roy DP, Wulder MA, Loveland TR, Woodcook CE, Allen RG, Anderson MC, Helder D, Irons JR, Johnson DM (2014) Landsat-8: Science and product vision for terrestrial global change research. Remote Sensing of Environment 145:154-172. DOI:

https://doi.org/10.1016/j.rse.2014.02.001

Silva Júnior MC, Pinto FAC, Fonseca DM, Queiroz DM, Maciel BF (2008) Deteç̧ão do efeito da adubação nitrogenada em Brachiaria decumbens Stapf. utilizando um sistema de sensoriamento remoto. Revista Brasileira de Zootecnia 37(3):411-419. DOI: https://doi.org/10.1590/S1516-35982008000300005
Soares Neto JP, Bezerra ARG, Noscon ES (2013) Probabilidade e análise decadal da precipitação pluvial da cidade de Barreiras-Bahia, Brasil. Revista Brasileira de Geografia Física 6(3):470-477.

Souza EG, Rocha T, Uribe-Opazo MA, Nóbrega LHP (2009) Vegetation índices in the maize as a function of hour of the day and the applied rate of nitrogen. Revista Brasileira de Engenharia Agrícola e Ambiental 13:865872. DOI: https://doi.org/10.1590/S141543662009000700008

Teixeira AHC, Bastiaanssen WGM, Ahmad MD, Bos MG (2009) Reviewing SEBAL input parameters for assessing evapotranspiration and water productivity for the LowMiddle São Francisco River basin, Brasil Part A: Calibration and validation. Agricultural and Forest Meteorology 6(3-4):462-476. DOI:

https://doi.org/10.1016/j.agrformet.2008.09.016

Tillack A, Clasen A, Kleinschmit B, Förster M (2014) Estimation of the seasonal leaf area index in an alluvial forest using high-resolution satellite-based vegetation indices. Remote Sensing of Environment 141:52-63. DOI: https://doi.org/10.1016/j.rse.2013.10.018

Yu L, Huang J, Zong S, Huang H, Luo Y (2018) Detecting Shoot Beetle Damage on Yunnan Pine Using Landsat Time-Series Data. Forests 9(39):5-14. DOI: http://dx. doi:10.3390/f9010039

Zhang Q, Li Q, Zhang G (2012) Rapid Determination of Leaf Water Content Using VIS/NIR Spectroscopy Analysis with Wavelength Selection. Spectroscopy: An International Journal 2(2):93-105. DOI: https://doi.org/10.1155/2012/276795

Zhang C, Pattey E, Liu J, Cai H, Shang J, Dong T (2018) Retrieving leaf and canopy water content of winter wheat using vegetation water indices. IEEE Journal of Selected Topics in Applied Earth Observations and Remote Sensing 11(1):112-126 